\title{
THE ACCURACY OF COMMERCIAL PROPERTY FORECASTING IN AUSTRALIA
}

\author{
GRAEME NEWELL and JOHN MacFARLANE \\ University of Western Sydney
}

\begin{abstract}
Commercial property forecasting is an important component within a property investment strategy. Using the Australian Property Institute's “Australian Property Directions Survey", this six-monthly survey amongst independent commercial property forecasters in Australia is used to compare commercial property forecasts with actual commercial property performance to assess the accuracy of commercial property forecasting in Australia over 1999-2005. The accuracy of this commercial property forecasting is also benchmarked against a number of alternative naive property forecasting strategies to assess the "added-value" of commercial property forecasting in Australia.
\end{abstract}

Keywords: Commercial property forecasting, API property sentiment survey, forecast versus actual performance, accuracy, optimistic forecasts, naïve property forecasting strategies.

\section{INTRODUCTION}

Commercial property forecasting is an important component in property investment decision-making (Chaplin, 1999; Mitchell and McNamara, 1997). While all forecasting is subject to some degree of uncertainty, a high degree of sophistication has been developed over recent years, with a range of advanced quantitative and qualitative procedures now used in commercial property forecasting, including judgemental procedures, causal/econometric procedures and time series/trend analysis procedures (Higgins, 2000; Rowland and Kish, 2000). The role of judgement, in which property forecasts are mediated and reviewed within property organizations, has also been highlighted (Gallimore and McAllister, 2004).

This has seen numerous property forecasting studies in forecasting property rents, stock levels, returns, yields and cash flows (eg: Brooks and Tsolacos, 2001; Chaplin, 1998, 1999, 2000; Matysiak and Tsolacos, 2003), econometric and structural modelling (eg: Chaplin, 1999; Matysiak and Tsolacos, 2003; Tsolacos,1998) and the comparison of forecasting procedures (eg: Ball and Tsolacos, 2002; Brooks and Tsolacos, 2001; Chaplin, 
1998, 2000; Newell and Karantonis, 2003; Stevenson and McGrath, 2003; Wilson and Okunev, 2001; Wilson et al, 2000)

Despite this increased sophistication in commercial property forecasting methodologies, differences in property forecasts still occur due to differences in the structure of the econometric models, statistical procedures and data used (Mitchell and McNamara, 1997), as well as the use of potentially flawed economic forecasts and poor data (Ball and Tsolacos, 2002; Higgins, 2001). In many instances, simple forecasts (eg: via naïve predictors) have been found to be more accurate than using complex econometric models (Chaplin, 1999, 2000; Higgins, 2001; Wilson et al , 2000).

Assessing the accuracy of economic forecasts has been regularly conducted; for example, IMF forecasts (Arora and Smyth, 1990) and OECD forecasts (Ash et al, 1990), with professional forecasters often seen to add little to forecasts generated by simple models (Leitch and Tanner, 1995) or to perform poorly (Chumacero, 2001; O'Connor, 1997). However, the equivalent level of analysis of the accuracy of property forecasts has not been conducted, with much of this property forecasting research focusing on developing a suitable model, with-holding data and testing the model's predictive ability, rather than using industry expert opinion-based property forecasts.

Previous research assessing the accuracy of property industry expert forecasts has found significant concerns over the accuracy of these property forecasts. In particular, Ling (2005) found no positive correlation between property analysts' forecasts and actual property return performance in the US over 1991-2000. Similarly, McAllister et al (2005) found high levels of uncertainty in the UK Investment Property Forum consensus forecasts (IPF, 2005) over 1999-2004, as well as Newell and Karantonis (2003) finding that naïve property forecasts performed at least as well as the current investor sentiment procedures (Jones Lang LaSalle) in Australia over 1991-2000.

To date, previous research into property forecasting in Australia has been limited. Only Newell and Karantonis (2003) for the direct property markets and Higgins (2005a) for the listed property trust market have considered the accuracy of commercial property forecasts, while Parker et al (2003) has developed a forecasting model for the Sydney CBD office market based on the RICS London office vacancy model. As such, the purpose of this paper is to use the Australian Property Institute's “Australian Property Directions Survey" of consensus-based property forecasts to assess the accuracy of commercial property forecasting in Australia over 1999-2005 ${ }^{(1)}$. In particular, the issues of forecasting uncertainty, forecasting disagreement, identification of commercial property market turning points, optimistic versus pessimistic forecasts and benchmarking against naïve commercial property forecasting strategies will be assessed to determine the added-value of commercial property forecasting in Australia.

\footnotetext{
(1) Only commercial property forecasts are considered in this paper.

$312 \quad$ Pacific Rim Property Research Journal, Vol 12, No 3
} 


\section{SIGNIFICANCE OF COMMERCIAL PROPERTY IN AUSTRALIA}

To highlight the need for accurate commercial property forecasting in Australia, the significant stature of commercial property in Australia needs to be established. The commercial property markets in Australia are the 12th largest in the world, accounting for $1.4 \%$ of global commercial property (PREI, 2003), with the established, mature commercial property markets in Australia seen as the most transparent property markets in the world (JLL, 2004). Amongst the global office markets, Sydney is seen to be the fourth most attractive location regarding property investment location risk (DEGI, 2005), with Australia seen as the 10th most competitive of the global economies (WEF, 2005).

The value of Australian commercial property has been estimated to be $\$ 332$ billion, with a core property market of $\$ 154$ billion (Higgins, 2005b). These commercial property markets have significant levels of institutional investor involvement through a wide range of property investment vehicles, including listed property trusts, unlisted wholesale funds, property syndicates and unlisted property trusts, accounting for over $\$ 160$ billion in total assets (PIR, 2004). The leading property fund managers include Westfield (total assets of $\$ 32$ billion), Colonial First State (\$21 billion) and AMP Capital (\$14 billion) (PIR, 2004).

With commercial property (direct property and LPTs) accounting for approximately $9 \%$ of institutional portfolios, Table 1 shows the investment performance of commercial property compared to the other major asset classes over 1, 3,5 and 10-year holding periods (PCA/IPD, 2005; UBS, 2005). This significant investment performance by each of the property sectors, and by both direct and indirect property (LPTs), is further reinforced by the portfolio diversification benefits reflected in the correlations between property and shares $(r=-0.03)$ and between property and bonds $(r=-0.24)(P C A / I P D, 2005)$. The portfolio diversification and risk reduction benefits of Australian commercial property have been further enhanced in recent years (Newell, 2005).

Specifically, for the Australian office markets, over 19.6 million $\mathrm{m}^{2}$ in total stock was available at June 2005 , comprising CBD office (70\%) and non-CBD office (30\%). Sydney (33\%) and Melbourne (25\%) dominate the total stock profile for the Australian CBD office market (PCA, 2005). Current national office market vacancy rates are $8.2 \%$, comprising Sydney CBD (10.2\% vacancy rate) and Melbourne CBD ( $7.7 \%$ vacancy rate) (PCA, 2005).

Overall, the above analysis confirms the significant role and performance of commercial property in investment portfolios in Australia, and hence the need for accurate commercial property forecasts for effective commercial property investment decision-making. 
Table 1: Asset class performance analysis: June 2005

\begin{tabular}{lrrrr}
\hline \multirow{2}{*}{ Asset class } & \multicolumn{4}{c}{ Average annual total return (\%) } \\
& \multicolumn{1}{c}{$\mathbf{1 Y}$} & \multicolumn{1}{c}{$\mathbf{3 Y}$} & $\mathbf{5 Y}$ & \multicolumn{1}{l}{$\mathbf{1 0 Y}$} \\
\hline Direct property & $13.84 \%$ & $11.96 \%$ & $11.30 \%$ & $10.45 \%$ \\
Office & $8.99 \%$ & $7.79 \%$ & $8.56 \%$ & $8.73 \%$ \\
Retail & $17.47 \%$ & $15.53 \%$ & $13.56 \%$ & $11.70 \%$ \\
Industrial & $14.52 \%$ & $13.68 \%$ & $13.24 \%$ & $13.73 \%$ \\
& & & & \\
LPTs & $17.35 \%$ & $15.55 \%$ & $15.13 \%$ & $13.23 \%$ \\
Office & $19.90 \%$ & $9.60 \%$ & $11.40 \%$ & $10.50 \%$ \\
Retail & $24.00 \%$ & $20.30 \%$ & $17.90 \%$ & $15.60 \%$ \\
Industrial & $38.00 \%$ & $22.30 \%$ & $20.40 \%$ & $16.70 \%$ \\
Diversified & $6.10 \%$ & $12.40 \%$ & $13.10 \%$ & $12.10 \%$ \\
& & & & \\
Shares & $23.95 \%$ & $14.48 \%$ & $9.28 \%$ & $11.78 \%$ \\
Bonds & $11.41 \%$ & $7.19 \%$ & $6.61 \%$ & $7.66 \%$ \\
\hline
\end{tabular}

Sources: PCA/IPD (2005), UBS (2005)

\section{METHODOLOGY}

\section{Commercial property forecasts}

The Australian Property Institute (API) conducts the "Australian Property Directions Survey" on a six-monthly basis (API, 2005). Surveys are conducted in April and September each year, commencing in September 1998. A wide range of commercial property information is collected, including percentage market growth projections above CPI over the next twelve months. These one year ahead real capital growth forecasts are available for the Sydney CBD office, Sydney non-CBD office, Sydney retail and Sydney industrial property markets for September 1999 - April $2005^{(2)}$, with twelve of these API surveys assessed in this paper.

\footnotetext{
(2) Since September 2003, forecasts are also available for the CBD office, retail and industrial property markets in Melbourne and Brisbane. This shorter timeframe for Melbourne and Brisbane only sees the Sydney commercial property market forecasts analysed in this paper.

$314 \quad$ Pacific Rim Property Research Journal, Vol 12, No 3
} 
Respondents to the survey include the leading commercial property players in Australia in the areas of property fund managers, property analysts and valuers; see Table 2 . The forecast results are presented at a consensus level, with individual respondent results being anonymous and not reported or recorded by the API. As such, the performance of individual property forecasters is unable to be evaluated. Whilst the respondents are not specifically professional property forecasters, they are major users of property forecasts, and hence have a good understanding of commercial property market dynamics. One year ahead forecasts are presented for the total group of respondents, as well as for the subgroups of property fund managers, property analysts and valuers. An average of 29 respondents have participated in these API forecasting surveys (see Table 2), with the respondent profile and numbers similar to that of the IPF survey of independent forecasts conducted in the UK (IPF, 2005).

Table 2: API survey respondent profile

Period of survey: September 1998 - September 2005

Frequency of survey: six-monthly (typically April, September)

Property forecast: one year ahead capital growth (real)

Number of participants: average $=29$; range $=23-36$

Sub-group participant numbers:

- $\quad$ property fund managers: average $=9 ;$ range $=6-11$

- $\quad$ property analysts: average $=9 ;$ range $=6-14$

- $\quad$ valuers: average $=11$; range $=8-13$

Typical respondents to survey include:

CB Richard Ellis, Citigroup, Colliers International, Colonial First State, DB RREEF, Ernst \& Young, GPT, Herron Todd White, ING Real Estate, Investa, Jones Lang LaSalle, Knight Frank, LandMark White, Macquarie, Merrill Lynch, QIC, Savills, Stockland, UBS, Westpac

Source: API (2005)

\section{Actual commercial property performance}

The PCA/IPD direct property indices are the benchmark series for commercial property performance in Australia, based on the performance of over 470 commercial properties valued at over $\$ 45$ billion at June 2005 (PCA/IPD, 2005). Real capital returns were assessed for the respective time periods for the following commercial property markets (PCA/IPD, 2005):

- Sydney CBD office: 49 properties valued at $\$ 9.9$ billion,

- Sydney non-CBD office: 24 properties valued at $\$ 1.5$ billion,

- Sydney retail: 63 properties valued at $\$ 8.9$ billion,

- Sydney industrial: 55 properties valued at $\$ 1.2$ billion. 


\section{Statistical analysis}

A range of statistical procedures was used to assess the accuracy of these commercial property forecasts over 1999-2005. In particular, Theil's U-statistic (Makridakis et al, 1998) was used to benchmark these commercial property forecasts against alternative naïve property forecasting strategies. Theil's U-statistic is the ratio of the root mean square error of the commercial property forecasting results divided by the root mean error of the naïve property forecasting results. Theil's U-statistic has been used previously in benchmarking commercial property forecasting ability (eg: Chaplin, 1999, 2000; Higgins, 2000, 2005a; McAllister et al, 2005; Newell and Karantonis, 2003).

The two naïve property forecasting strategies used in this study were:

- $\quad$ strategy \#1: “zero real growth" and

- strategy \#2: "same change" in which the previous one-year actual real value was used as the forecast for the subsequent year.

In interpreting Theil's U-statistic:

- $\mathrm{U}=1$ indicates the naïve property forecasting strategy is as good as the consensus property forecasts,

- $\mathrm{U}<1$ indicates the consensus property forecasts are better than the naïve property forecasting strategy,

- $\mathrm{U}>1$ indicates the consensus property forecasts are worse than the naïve property strategy.

\section{RESULTS AND DISCUSSION}

\section{Accuracy of commercial property forecasts: uncertainty}

To assess the level of uncertainty in commercial property forecasting, Figure 1 presents the forecast and actual performance for Sydney CBD office, non-CBD office, retail and industrial property over 1999-2005. For Sydney CBD office, the forecasts were optimistic in every time period, with forecasts also effectively identifying each of the turning points in the Sydney CBD office market. Forecasts were also generally optimistic for Sydney non-CBD office, with the lesser ability to identify market turning points reflecting some degree of inertia ${ }^{(3)}$ and the lesser level of market information available for this particular property market sector. Retail forecasts tended to be stable over 1999-2005 and not capturing the strong retail market performance since 2003, with forecasts also generally being conservative. Industrial forecasts tended to also be conservative, under-estimating in

\footnotetext{
${ }^{(3)}$ Inertia reflects property forecasts being slow to respond to changes in property market.
} 
an improving market and over-estimating in a declining market. There was also less evidence of identifying individual market turning points.

The reasonably consistent over-estimation of forecast growth in the Sydney office market raises the question of whether the forecasters have taken account of inflation (the forecasts requested are for growth over inflation and this is explicitly stated in the survey question), but this phenomenon was not evident for the forecasts in the retail and industrial sectors.

Table 3 presents the mean absolute differences between the forecast and actual values over 1999-2005 for the four property sectors and for the three property forecaster subgroups (eg: fund managers, property analysts, valuers). Overall, the industrial sector was the most accurately forecast, with the CBD office market being the least accurately forecast. There was no evidence of differences in forecasting ability in the four property sectors for fund managers, property analysts and valuers, as well as each of the three groups forecasting the industrial sector most accurately and the CBD office sector least accurately.market sector. Retail forecasts tended to be stable over 1999-2005 and not capturing the strong retail market performance since 2003, with forecasts also generally being conservative. Industrial forecasts tended to also be conservative, under-estimating in an improving market and over-estimating in a declining market. There was also less evidence of identifying individual market turning points.

Table 3: Mean absolute differences: 1999 - 2005

\begin{tabular}{lllll}
\hline & Overall & Fund managers & Property analysts & Valuers \\
CBD office & $3.41 \%$ & $3.58 \%$ & $3.48 \%$ & $3.21 \%$ \\
Non-CBD office & $2.30 \%$ & $2.25 \%$ & $2.68 \%$ & $2.11 \%$ \\
Retail & $2.73 \%$ & $2.85 \%$ & $2.56 \%$ & $2.79 \%$ \\
Industrial & $1.42 \%$ & $1.56 \%$ & $1.54 \%$ & $1.62 \%$ \\
\hline
\end{tabular}

Source: Authors' calculation 
Figure 1: Forecast versus actual performance: 1999 - 2005

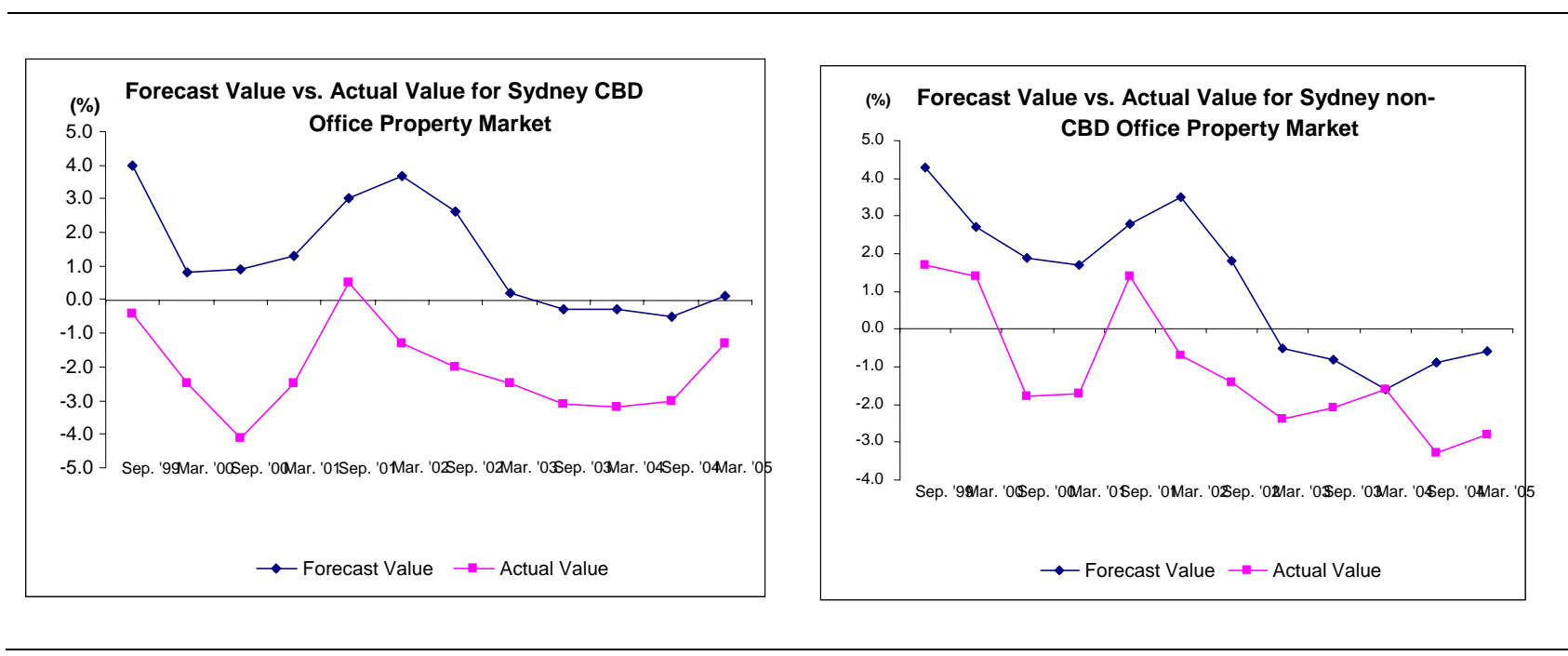



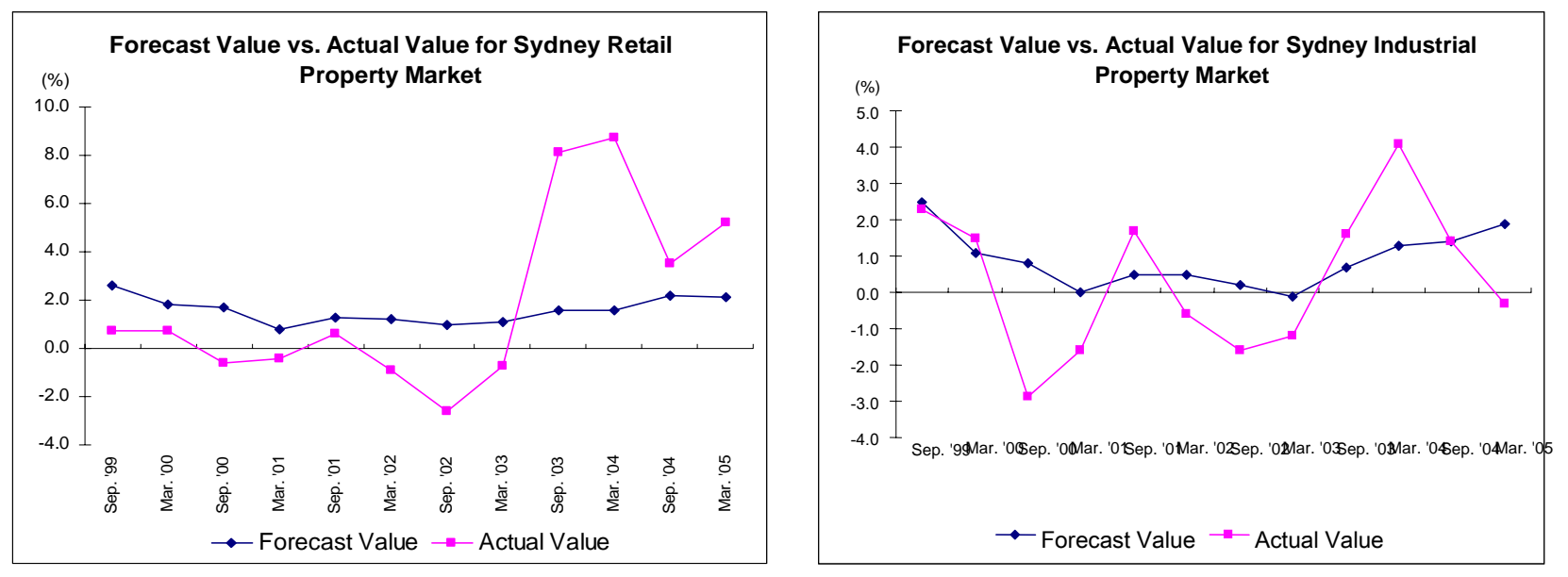

Source: Authors' calculation 


\section{Accuracy of commercial property forecasts: disagreement}

Another dimension of commercial property forecasting is assessing whether forecasters disagree amongst themselves in specific time periods. This can be assessed by the standard deviation of the absolute differences between forecasts and actuals per time period, with the smaller the standard deviation reflecting less disagreement amongst the property forecasters. Table 4 gives the average standard deviations over 1999-2005 for the four property sectors and three property forecasting sub-groups. Overall, property forecasters were more in agreement for the industrial and retail sectors and more variable as a group for the CBD office and non-CBD office sectors, with this also being the case for the fund managers, property analysts and valuers when forecasting these four property sectors. Each of the three property forecasting sub-groups showed similar levels of disagreement for each of the property sectors.

Table 4: Average standard deviation of absolute differences: 1999 - 2005

\begin{tabular}{lllll}
\hline & Overall & Fund managers & Property analysts & Valuers \\
CBD office & 2.80 & 2.60 & 2.96 & 2.65 \\
Non-CBD office & 3.00 & 2.88 & 3.19 & 2.58 \\
Retail & 2.40 & 2.23 & 2.17 & 2.28 \\
Industrial & 2.17 & 1.97 & 2.08 & 2.08 \\
\hline
\end{tabular}

Source: Authors' calculation

\section{Are commercial property forecasters optimistic or pessimistic?}

Table 5 presents the incidence of optimistic forecasts (ie: where the forecast value exceeds the actual value) for the four property sectors over 1999-2005. Forecasters were most optimistic for the Sydney CBD office and non-CBD office sectors, being optimistic in each of the twelve time periods. The levels for retail $(67 \%)$ and industrial $(62 \%)$ were also favouring the tendency to be optimistic with forecasts. Typically, there would be "runs" of over-estimating (optimistic) or under-estimating (pessimistic) actual performance; for example, see Figure 1 regarding retail property. No major differences were seen regarding this incidence of optimistic forecasting amongst fund managers, property analysts and valuers.

Table 5: Incidence of optimistic forecasts (versus actual): 1999 - 2005

\begin{tabular}{lllll}
\hline & Overall & Fund managers & Property analysts & Valuers \\
CBD office & $100 \%$ & $100 \%$ & $100 \%$ & $100 \%$ \\
Non-CBD office & $100 \%$ & $92 \%$ & $92 \%$ & $100 \%$ \\
Retail & $67 \%$ & $75 \%$ & $67 \%$ & $67 \%$ \\
Industrial & $62 \%$ & $67 \%$ & $58 \%$ & $50 \%$
\end{tabular}

Source: Authors' calculation 
Relative to the consensus forecasts, Table 6 presents the level of optimistic forecasts for fund managers, property analysts and valuers over 1999-2005. Benchmarked against these consensus results, property analysts were consistently seen to be the most optimistic for CBD office and non-CBD office, while fund managers were consistently the most optimistic for retail and industrial property. Relative to fund managers and property analysts, valuers were not seen to be consistently optimistic for any of the four property sectors.

Table 6: Incidence of optimistic forecasts (versus consensus): 1999 - 2005

\begin{tabular}{lccc}
\hline & Fund managers & Property analysts & Valuers \\
CBD office & $50 \%$ & $58 \%$ & $42 \%$ \\
Non-CBD office & $37 \%$ & $62 \%$ & $42 \%$ \\
Retail & $87 \%$ & $62 \%$ & $21 \%$ \\
Industrial & $62 \%$ & $33 \%$ & $46 \%$
\end{tabular}

Source: Authors' calculation

\section{Commercial property forecasting versus naïve commercial property forecasts}

Using Theil's U-statistic, Table 7 compares the consensus property forecasts with the naïve property forecasting strategies of "zero growth" and "same change" over 19992005. Property forecasters were seen to outperform these naïve property forecasting strategies for both retail and industrial property, but not in the case of CBD office or nonCBD office property. Similar forecasting out-performance for retail and industrial property was also evident for each of fund managers, property analysts and valuers, with no differences seen between the forecasting ability of the three groups relative to the naïve forecasting strategies. 
Table 7: Commercial property forecasts versus naïve forecasting strategy: Theil's U-statistic ${ }^{(1)}$

Naïve forecasting strategy \#1: Zero growth

$\begin{array}{lllll} & \text { Overall } & \text { Fund managers } & \text { Property analysts } & \text { Valuers } \\ \text { CBD office } & 1.46 & 1.54 & 1.57 & 1.40 \\ \text { Non-CBD office } & 1.30 & 1.34 & 1.52 & 1.22 \\ \text { Retail } & \mathbf{0 . 8 5} & \mathbf{0 . 8 8} & \mathbf{0 . 8 1} & \mathbf{0 . 9 0} \\ \text { Industrial } & \mathbf{0 . 8 9} & 1.05 & \mathbf{0 . 8 9} & \mathbf{0 . 9 1}\end{array}$

Naïve forecasting strategy \#2: Same change

\begin{tabular}{lllll} 
& Overall & Fund managers & Property analysts & Valuers \\
CBD office & 1.58 & 1.66 & 1.69 & 1.52 \\
Non-CBD office & 1.10 & 1.14 & 1.29 & 1.03 \\
Retail & $\mathbf{0 . 7 4}$ & $\mathbf{0 . 7 7}$ & $\mathbf{0 . 7 0}$ & $\mathbf{0 . 7 8}$ \\
Industrial & $\mathbf{0 . 5 2}$ & $\mathbf{0 . 6 2}$ & $\mathbf{0 . 5 3}$ & $\mathbf{0 . 5 4}$ \\
\hline
\end{tabular}

(1) Theil's U-statistic values in bold indicate consensus commercial property forecasts were better than the naïve forecasting strategy.

\section{COMMERCIAL PROPERTY FORECASTING IMPLICATIONS}

Commercial property forecasting is an essential but difficult process in property investment decision-making, being subject to uncertainty and the impact of unexpected shocks. Using the API "Australian Property Directions Survey" one-year ahead forecasts for Sydney CBD office, non-CBD office, retail and industrial property over 1999-2005, the key commercial property forecasting issues to emerge are:

- forecasters tended to be consistently optimistic; particularly for Sydney CBD office and non-CBD office property

- forecasters tended to be conservative; particularly for industrial and retail property

- forecasters were most effective in getting the market turning points correct for $\mathrm{CBD}$ office and to a lesser degree for non-CBD office 
- $\quad$ some inertia was present in forecasters responding to changes in the market

- forecasting uncertainty was a more critical issue than forecasting disagreement

- forecasters out-performed naïve property forecasting strategies for industrial and retail property, but not for $\mathrm{CBD}$ office and non-CBD office property

- no significant differences were evident in commercial property forecasting ability for fund managers, property analysts and valuers, although valuers tended to be less optimistic than the other two groups of property forecasters.

Importantly, these results have raised similar issues and concerns regarding the accuracy of commercial property forecasting to that seen in the UK (McAllister et al, 2005) and US (Ling, 2005); particularly concerning commercial property forecasting uncertainty, disagreement, conservative forecasting and inertia.

\section{REFERENCES}

Arora, H. and Smyth, D. (1990), "Forecasting the developing world: an accuracy analysis of the IMF's forecasts", International Journal of Forecasting, Vol. 6, pp. 393-400.

Ash, J., Smyth, D. and Heraiu, S. (1990), "The accuracy of OECD forecasts of the international economy", International Journal of Forecasting, Vol. 6, pp. 379-392.

Australian Property Institute (2005), Australian Property Directions Survey: April 2005. API, Sydney (and miscellaneous previous copies).

Ball, M. and Tsolacos, S. (2002), "UK commercial property forecasting: the devil is in the data”, Journal of Property Research, Vol. 19, pp.13-38.

Brooks, C. and Tsolacos, S. (2001), "Forecasting real estate returns using financial spreads", Journal of Property Research, Vol. 18, pp. 235-248.

Chaplin, R. (1998), “An ex-post comparative evaluation of office rent prediction models", Journal of Property Valuation and Investment, Vol. 16,pp. 21-37.

Chaplin, R. (1999), “The predictability of real office rents", Journal of Property Research, Vol. 16, pp. 21-49.

Chaplin, R. (2000),'Predicting real estate rents: walking backwards into the future", Journal of Property Investment and Finance, Vol. 18, pp. 352-370.

Chumacero, R. (2001), "Empirical analysis of systematic errors in Chilean GDP forecasts", Journal of Forecasting, Vol. 20, pp. 37-45.

DEGI (2005), Global Values: Property Investment 2005. DEGI, Frankfurt.

Gallimore, P. and McAllister, P. (2004), "Expect judgement in the processes of commercial property market forecasting", Journal of Property Research, Vol. 21, pp. 337360 . 
Higgins, D. (2000), "Current status of forecasting the performance of Australian commercial property markets", Australian Property Journal, Vol. 36, pp. 43-49.

Higgins, D. (2001), “The hidden property gamble”, Property Australia, Vol. 15, pp. 37 38.

Higgins, D. (2005a), "Forecasting short-term listed property trust returns", Australian Property Journal, Vol. 38, pp. 398-404.

Higgins, D. (2005b), "Modelling the Australian property investment universe: a preliminary study ”, Pacific Rim Property Research Journal, Vol. 11, pp. 268-281.

Investment Property Forum (2005), Survey of Independent Forecasts: UK Property Investment: November 2005. IPF, London.

Jones Lang LaSalle (2004), Global Real Estate Transparency Index 2004. JLL, Chicago.

Leitch, G. and Tanner, E. (1995), "Professional economic forecasts: are they worth their costs?", Journal of Forecasting, Vol. 14, pp. 143-157.

Ling, D. (2005), “A random walk down Main Street: can experts predict returns on commercial real estate?”, Journal of Real Estate Research, Vol. 27, pp. 137-154.

Makridakis, S., Wheelwright, S. and Hyndman, R. (1998), Forecasting Methods and Applications. John Wiley, New York.

McAllister, P., Newell, G. and Matysiak, G. (2005), Disagreement and Uncertainty in UK Property Market Forecasts. Investment Property Forum, London.

Matysiak, G. and Tsolacos, S. (2003), "Identifying short-term leading indicators for real estate rental performance", Journal of Property Investment and Finance, Vol. 21, pp. 212232.

Mitchell, P. and McNamara, P. (1997), "Issues in the development and application of property market forecasting: the investor's perspective", Journal of Property Finance, Vol. 8, pp. 363-376.

Newell, G. (2005), "The changing dynamics of Australian commercial property portfolios”, Australian Property Journal, Vol. 38, pp. 553-558.

Newell, G. and Karantonis, A. (2003), "The predictive accuracy of investor sentiment for commercial property in Australia", Journal of Financial Management of Property and Construction, Vol. 8, No.3, pp. 117-128.

O’Connor, M. (1997), “Going up-going down: how good are people at forecasting trends and changes in trends?", Journal of Forecasting, Vol. 16, pp. 165-176.

Parker, D., MacFarlane, J., Murray, J. and Peng, V. (2003), "Forecasting property market cycles: an application of the RICS model to the Sydney CBD office market", Journal of Financial Management of Property and Construction, Vol. 8, pp. 179-191. 
Property Council of Australia (2005), Australian Office Market Report: July 2005. PCA, Sydney.

Property Council of Australia/IPD (2005), Investment Performance Index: June 2005. IPD, Melbourne.

Property Investment Research (2004), Australian Property Funds Industry Survey 2004. PIR, Melbourne.

Prudential Real Estate Investors (2003), A Bird's Eye View of Global Real Estate Markets. PREI, Parsippany.

Rowland, P. and Kish, J. (2000), "Decision making by property fund managers: a survey”, Australian Property Journal, Vol. 36, pp. 104-111.

Stevenson, S. and McGrath, O. (2003), “A comparison of alternative rental forecasting models: empirical tests on the London office market", Journal of Property Research, Vol. 20, pp. 235-260.

Tsolacos, S. (1998), "Econometric modelling and forecasting of new retail developments", Journal of Property Research, Vol. 15, pp. 265-283.

UBS (2005), UBS Indices: June 2005. UBS, Sydney.

Wilson, P. and Okunev, J. (2001), "Enhancing information use to improve predictive performance in property markets", Journal of Property Investment and Finance, Vol. 19, pp. 472-497.

Wilson, P., Okunev, J., Ellis, C. and Higgins, D. (2000), "Comparing univariate forecasting techniques in property markets", Journal of Real Estate Portfolio Management, Vol. 6, pp. 283-306.

World Economic Forum (2005), Global Competitiveness Report: 2005-2006. WEF, Geneva. 